\title{
Benign paraproteinaemias
}

\author{
J. KOHN
}

From the Department of Chemical Pathology, Queen Mary's Hospital, London

A paraprotein can be defined in our present state of knowledge as a complete or incomplete immunoglobulin molecule, possibly abnormal, produced in excess by a single clone of immunocytes (Osserman and Fahey, 1968), and characterized on electrophoresis by a discrete band or peak. The discovery of a paraprotein in the plasma should not be regarded as synonymous with a malignant proliferative disease process and numerous authenticated cases prove that paraproteinaemia can be perfectly compatible with normal health. This was first noticed and reported by Waldenström in 1944 and has been confirmed since then by many observers. I shall use the term 'benign' paraproteinaemia to refer to this condition, ie, the occurrence of paraproteinaemia in the absence of detectable malignancy or other relevant pathology. Unfortunately some confusion has arisen owing to the wide variety of terms used to refer to this interesting but still ill understood and rather vaguely defined condition. A vast array of adjectives has been suggested and used by various authors, such as idiopathic, cryptogenic, rudimentary, lanthanic, discrete, sympton-poor, non-myelomatous, benign, coupled with nouns like monoclonal gammopathy, paraproteinaemia, dysimmunoglobulinaemia and dyscrasia.

The paraprotein is detected primarily by electrophoresis of serum proteins on a suitable medium such as cellulose acetate which, if properly carried out, can detect small amounts of paraprotein. The clearest separation patterns on cellulose acetate are achieved by first diluting the serum sample 10-20 times followed by Nigrosin staining; this gives results comparable with those obtained by electrophoresis on agarose. Some authors advocate immunoelectrophoresis on the grounds that it will detect smaller amounts of paraprotein than simple electrophoresis, but this is controversial and the technique is impracticable for mass screening. Visual inspection of the electrophoretic strip seems to be perfectly adequate, particularly if carried out by two experienced observers. The electrophoresis technique should spread the gamma fraction adequately, with an overall protein separation of at least $4 \mathrm{~cm}$. I do not consider the rapid techniques which distribute the proteins over only $2 \mathrm{~cm}$ to be satisfactory (Kohn, 1973).

Classification and typing of the paraprotein are performed by immunoelectrophoresis, using several dilutions of the serum sample to ensure optimal concentration of the paraprotein, thus avoiding prozone phenomena. For the detection of BenceJones protein in the urine a good electrophoretic technique using concentrated as well as unconcentrated urine is essential, and its presence is confirmed by immunoelectrophoresis with suitable light chain antisera.

\section{Incidence of Paraproteinaemia}

This is highly controversial. It depends on laboratory technique and to a very large extent on the population studied, especially with respect to age distribution and the inclusion of hospital patients (table $\mathrm{I}$ ). Our own experience, gained mainly from ill patients, is summarized in table II and shows a relatively small proportion of 'benign paraproteinaemias'; the proportion of proven immunocytomas is similar to that quoted by Hobbs (1971a).

Kohn and Srivastava (1972) reported 20 cases among 10000 blood donors, details of which are given in table III. In some sera the first indication of paraproteinaemia was the formation of a gel during routine inactivation of serum complement at $56^{\circ}$, indicating the presence of pyroglobulins. The main purpose in screening these donors was to establish a baseline for a subsequent long-term study. So far as we are aware, none of these cases of paraproteinaemia has shown overt malignancy, although in three of them the paraprotein levels rose after two years and reached a new plateau (see below). It must be enphasized, however, that in at least five other patients we have no follow up for the last few years.

There is a need for caution when interpreting population surveys. This is illustrated by table IV which shows the incidence of paraproteinaemia and its distribution in two elderly populations from different geographical regions.

The benign nature of a paraproteinaemia cannot 


\begin{tabular}{|c|c|c|c|c|c|}
\hline \multirow[t]{2}{*}{ Author } & \multirow[t]{2}{*}{ Age Group } & \multirow[t]{2}{*}{ Population Group } & \multirow[t]{2}{*}{ No. Examined } & \multicolumn{2}{|l|}{ Incidence $(\%)$} \\
\hline & & & & Paraproteinaemia & Overt Myeloma \\
\hline Axelsson and Hällén (1968) & $25-99$ & General population & 6995 & $1 \cdot 0$ & 0.03 \\
\hline \multirow{2}{*}{ Fine et al (1972) } & \multirow[t]{2}{*}{$26-60$} & Blood donors & 10300 & $0 \cdot 1$ & 0.03 \\
\hline & & Blood donors & 3100 & 0.3 & $0 \cdot 1$ \\
\hline Kohn and Srivastava (1972) & $20-62$ & Blood donors & 9420 & $0 \cdot 2$ & $\begin{array}{l}\text { No evidence after } \\
5 \text { years }\end{array}$ \\
\hline Fine et al (1966) & $>68$ & Old people's home & 500 & 3.0 & 0.4 \\
\hline Hällén (1963) & $>70$ & Old people's home & 294 & $3 \cdot 1$ & 0.0 \\
\hline Axelsson, Bachman, and Hällén (1966) & $>60$ & General population & 2043 & 1.4 & $0 \cdot 1$ \\
\hline Walsh et al (1971) & $>50$ & Psychiatric hospital & 1011 & $2 \cdot 1$ & 0.5 \\
\hline \multirow[t]{2}{*}{ Kohn and Srivastava (1972) } & $>60$ & $\begin{array}{l}\text { Outpatients } \\
\text { (geriatric) }\end{array}$ & 806 & $1 \cdot 8$ & $1 \cdot 2$ \\
\hline & $>60$ & $\begin{array}{l}\text { Inpatients } \\
\text { (geriatric) }\end{array}$ & 1000 & $3 \cdot 2$ & $2 \cdot 6$ \\
\hline \multirow[t]{3}{*}{ Englisova et al (1968) } & $65-79$ & & 369 & 1.6 & $?$ \\
\hline & $80-90$ & & 51 & $11 \cdot 7$ & $?$ \\
\hline & $>90$ & & 26 & $19 \cdot 0$ & ? \\
\hline Radl et al (unpublished) & $>95$ & Old people's home & 73 & $19 \cdot 0$ & $?$ \\
\hline Zawadzki and Edwards (1972) & $>70$ & Inpatients & 748 & $7 \cdot 5$ & $2 \cdot 0$ \\
\hline
\end{tabular}

Table I Incidence of paraproteinaemia in the general population, in blood donors and in the older age groups 1 ${ }^{1}$ Note the increased frequency of paraproteinaemia and overt myeloma with age, and the higher incidence in hospital patients.

\begin{tabular}{lr}
\hline Paraproteinaemias 1966-74 & $\begin{array}{c}\text { No. of } \\
\text { Cases }\end{array}$ \\
\hline Immunocytoma (myeloma, macroglobulinaemia) & 460 \\
Neoplasia other than above & 29 \\
Diagnosis unconfirmed, follow-up information inadequate & 131 \\
but immunocytoma distinct possibility & 57 \\
Considered to be benign (to date) & 677 \\
Total investigated & \\
\hline
\end{tabular}

Table II Incidence of immunocytoma and other conditions in our own cases of paraproteinaemia

be established with certainty without follow up over a number of years and the exclusion of such conditions as myeloma or macroglobulinaemia. Opinion is swinging away from the assumption that all paraproteinaemias are the result of some form of malignant immunocytoma to the opposite view that the great majority of paraproteinaemias are benign.

\begin{tabular}{|c|c|c|}
\hline & & $\begin{array}{l}\text { No. of } \\
\text { Cases }\end{array}$ \\
\hline \multicolumn{2}{|c|}{$\begin{array}{c}\text { Paraproteinaemia : Monoclonal } \\
\text { Biclonal }\end{array}$} & $\begin{array}{r}18 \\
2\end{array}$ \\
\hline \multicolumn{2}{|c|}{ Pyroglobulin detected on first occasion } & 2 \\
\hline \multicolumn{2}{|c|}{$\begin{array}{c}\text { Immunosuppression : Significant } \\
\text { Mild IgA }\end{array}$} & $\begin{array}{l}1 \\
1\end{array}$ \\
\hline \multicolumn{2}{|c|}{$\begin{array}{c}\text { Bence-Jones protein in urine: } \\
\text { Trace }\end{array}$} & $\begin{array}{l}1 \\
1\end{array}$ \\
\hline ESR $\begin{array}{r}3 \mathrm{~mm} / \mathrm{hr} \\
3-10 \mathrm{~mm} / \mathrm{hr} \\
10-30 \mathrm{~mm} / \mathrm{hr}\end{array}$ & Wintrobe & $\begin{array}{l}2 \\
4 \\
6\end{array}$ \\
\hline \multicolumn{2}{|l|}{ Not examined } & 8 \\
\hline
\end{tabular}

Table III Laboratory data relating to 20 blood donors with paraproteinaemia detected on screening (Kohn and Srivastava, 1972)

\begin{tabular}{lccr}
\hline & Region A & Region B & Total \\
\hline Total number tested & 500 & 500 & 1000 \\
Paraproteinaemia & 15 & 22 & 37 \\
Myeloma & 2 & 1 & 3 \\
Lymphoproliferative & 1 & 6 & 7 \\
Coexisting with cancer & - & 4 & 4 \\
Non-neoplastic & - & 3 & 30 \\
'Benign', 'idiopathic' & 12 & 80 \\
\hline
\end{tabular}

Table IV Incidence of benign and malignant paraproteinaemia in subjects aged over 70 years in two geographical regions (Fine, Derycke, and Boffa, 1966)

\section{Criteria of Malignancy}

There are no certain criteria for establishing that paraproteinaemia is benign although there are $a$ number of features which may help to determine thaf the condition is malignant. Unfortunately, laboratory tests are not absolutely reliable in this respect? There are no well defined differences in the molecula 5 structure of a malignant paraprotein and no differen ces of class or subclass, there are no characteristie cytoenzymatic features, and even electron micro scopy does not reveal reliable markers of malignancy. or, for that matter, the opposite. The long natura history of the condition makes a follow up verye protracted.

The following criteria are most helpful in the्టे differential diagnosis of paraproteinaemia:-(1) The absolute concentration of the paraprotein; (2) evidence of increasing serum concentration of the paraprotein; (3) suppression of formation of immunoglobulins other than the paraprotein; (4) presence of significant amounts of Bence-Jones protein in the urine; (5) a characteristic bone 
marrow picture; (6) results of the skeletal axis $x$-ray examination. The presence of at least three of the laboratory criteria can be regarded as indicative of malignancy.

The age of the patient must also be taken into consideration; the finding of paraproteinaemia in an infant or child has ominous implications (unless it is also present in the mother). The majority of such children so far reported suffered from one of the immune deficiency states, and death due to infection or malignant disease usually occurred within a few months or years.

The presence or absence of immunosuppression is a very valuable diagnostic pointer. Hobbs (1967) found immunosuppression in $98 \%$ of patients with myeloma, and we have found it in $87 \%$. It frequently first affects the IgA, particularly in the IgG type of myeloma. Conversely, in benign paraproteinaemia immunosuppression is rare, and it may not occur in macroglobulinaemia, increased values of the noninvolved immunoglobulins sometimes being found.

The presence of increased amounts of BenceJones protein in the urine is a very ominous sign and has only rarely been observed in benign paraproteinaemia. One such patient investigated by Kanoh (personal communication) excerted considerable amounts of Bence-Jones protein without showing any signs of malignancy over a period of 10 years. A similar case, which has now been under observation for a number of years, was reported by Osserman (1971), and Kyle, Maldonado, and Bayrd (1973) reported two more cases which were diagnosed by the heat test for Bence-Jones protein. The excretion of relatively small amounts of Bence-Jones protein in the absence of myeloma or macroglobulinaemia has been described by Damacco and Waldenström (1968) among others. It is now generally held that a value above $60 \mathrm{mg} / 100 \mathrm{ml}$ is very rarely found in benign paraproteinaemia, although some authors would put the figure as low as $10 \mathrm{mg} /$ $100 \mathrm{ml}$ (Hobbs, 1976). The technique used for detecting Bence-Jones protein in urine is of course most important, and examination of concentrated urine is essential if negative results are obtained with an unconcentrated sample.

The total serum protein concentration is rarely increased in benign paraproteinaemia, and usually the level of paraprotein is relatively low, rarely exceeding $20 \mathrm{~g} / 1$ for IgG and $10 \mathrm{~g} / 1$ for IgA or IgM. Hobbs (1967) reported that in $85 \%$ of patients regarded as having a benign condition the initial paraprotein level did not exceed $10 \mathrm{~g} / \mathrm{l}$, whereas in patients with malignancy $92 \%$ had paraprotein levels greater than this. An important but sometimes overlooked cause of falsely elevated proteins, particularly with small samples, is evaporation. It may be caused by centrifuging for prolonged periods with a resulting rise in temperature.

Perhaps the most important procedure in an apparently benign paraproteinaemia is to follow the total protein and paraprotein levels (Waldenström, 1973; Axelsson and Hällén, 1968; Hällén, 1966; Hobbs, 1971b; Zawadzki and Edwards, 1972). It must be stressed that the latter cannot be estimated accurately by immunological techniques (Jensen, Hom, Jensen, and Olesen, 1969; Blundell and Fitzpatrick, 1971; Kohn, 1973) as illustrated in table V. Electrophoresis followed by estimation of the concentration of the paraprotein by scanning or elution is essential and should be performed at three-monthly intervals for the first year and sixmonthly intervals thereafter.

In benign paraproteinaemia the level either remains constant over several years or rises slowly to a higher level and then stabilizes again. However, malignant evolution may occasionally occur after intervals of five to 18 years (Norgaard, 1964; Stevens, 1965; Kyle and Bayrd, 1966) as shown by an accelerated increase of the paraprotein level over a matter of months. It will probably be another decade before the natural history is well understood.

Pronounced hypoalbuminaemia is a frequent phenomenon in myelomatosis and primary macroglobulinaemia, but in benign paraproteinaemia it has been noted only in cases with a paraprotein concentration above $15 \mathrm{~g} / \mathrm{l}$. Other biochemical features of benign paraproteinaemia include normal plasma calcium and urea and, in the case of benign macroglobulinaemia, an absence of 7S-IgM (Hobbs, 1967).

The most important haematological information is provided by the appearance of the bone marrow. A

\begin{tabular}{|c|c|c|c|c|c|c|}
\hline \multirow[t]{2}{*}{ Serum } & \multicolumn{6}{|c|}{ Assay Plate Values ( $\mathrm{mg} \%)$} \\
\hline & $\boldsymbol{A}$ & $\boldsymbol{B}$ & $C$ & $D$ & $\boldsymbol{E}$ & $\boldsymbol{F}$ \\
\hline $\begin{array}{l}\text { IgG Myeloma } \\
\text { IgA Myeloma } \\
\text { IgM Paraprotein }\end{array}$ & $\begin{array}{l}640 \\
660 \\
370\end{array}$ & $\begin{array}{r}1190 \\
516 \\
500\end{array}$ & $\begin{array}{r}780 \\
1060 \\
513\end{array}$ & $\begin{array}{r}960 \\
1560 \\
300\end{array}$ & $\begin{array}{r}2040 \\
448 \\
418\end{array}$ & $\begin{array}{l}895 \\
660 \\
392\end{array}$ \\
\hline
\end{tabular}

Table V Results of immunoglobulin assay of three paraprotein-containing sera using six different commercial ${ }^{1}$ immunoplates $A$ to $F$ (by courtesy Dr Mahtre)

${ }^{1}$ Note large discrepancies between various brands. 
plasma cell count of over 20 to $25 \%$ with frequent mitoses, clumping, and abnormal cytoplasmic staining indicate malignancy. The proportion of plasma cells may increase in other conditions and it is the appearance rather than the cell count which matters for the diagnosis of myelomatosis. A raised ESR is another important feature which very often draws attention to the possibility of myeloma. In benign paraproteinaemia the ESR is usually normal or only moderately increased. A high ESR may, in fact, precede overt malignancy by quite a long time, and may therefore be regarded as a warning sign. Similarly, cases have been described in which serum exhibited anticomplementary activity up to 17 years before the onset of malignant myeloma (Norgaard, 1964). Benign paraproteinaemia does not cause anaemia, and a haemoglobin level below 10 or $11 \mathrm{~g} / 100 \mathrm{ml}$ suggests malignancy.

A full clinical assessment and an $x$-ray examination of the skeleton are absolutely essential. Certain bone lesions are typical of myeloma, but they may not be demonstrable radiologically in about $20 \%$ of cases. It has been estimated that a myelomatous focus will not be visible radiologically unless it has destroyed more than $25 \%$ of the local bone trabeculae.

\section{Management}

The most important procedure in the absence of firm evidence of malignancy is a long-term follow up but this is only possible in a proportion of cases. Not only may this reveal an unchanging paraprotein concentration but, in some subjects, the paraproteinaemia will be found to be transient, a phenomenon recorded in association with a heterogeneous assortment of diseases, including acute and chronic infections, collagen diseases, cirrhosis, genetically determined immune deficiency states, successfully treated non-reticular neoplasms, prosthetic heart valve insertion, and other conditions, including malaria, folic acid deficiency, gastric ulcer, and cold sensitivity (Young, 1969; Cooke, 1969; Danon and Seligmann, 1972). The significance of transient paraproteinaemia is not yet clear, but in some cases it represents a monoclonal antibody response to an antigen.

If the detection of paraproteinaemia is a chance finding in an otherwise normal and healthy person, more elaborate or invasive investigations are hardly justified. If, however, the patient is in hospital, perhaps with a suggestion of malignant disease, additional investigations such as bone marrow biopsy and $x$-ray examination may be indicated. It is important to treat the disease rather than the paraproteinaemia and, so long as malignant disease is not demonstrable, no treatment should be given. There is even a suspicion that the use of cytotoxic drugs such as melphalan or cyclophosphamide mayo induce or accelerate the emergence of acute leukae $-\vec{\Rightarrow}$ mia in cases of myeloma. Even if this fear proves to $\stackrel{\infty}{\rightarrow}$ be groundless, the treatment of asymptomatic paraproteinaemia can hardly be justified in the light $\frac{\overline{\bar{c}}}{\bar{D}}$ of our present understanding of the natural history of this disorder.

The difficulty lies in deciding at what stage to start treatment of a patient with some suggestivefeatures but no proof of malignancy. Some workers have claimed that early treatment is likely to be the $\vec{\omega}$ most successful. It is difficult to lay down hard and fast rules and each case should be considered on itso merits.

\section{Natural History}

This almost by definition must be very long. In aO considerable number of reported cases no overt manifestations of malignancy could be detecteck during the life span of the patient, and there are cases on record in which good health was maintained for more than 20 or even 30 years after discovery of the paraprotein (Norgaard, 1964; Stevens, 1965) $\vec{\varphi}$ However, as many paraproteinaemias are discoveredr in old age, the observation period is usually quited limited. There are also indications that patients wh benign paraproteinaemia are more susceptible to $_{5}$ other diseases than the normal population (Zawadzk and Edwards, 1972).

\section{Pathogenesis and Aetiology}

An outstanding problem is identification of the site of production of the paraprotein. In the absence of demonstrable foci of paraprotein-synthesizing cells? a generalized distribution of those cells must be presumed, but the factors which trigger such change and maintain it in a relatively restricted? manner are unknown. Radl and Hollander (1974) noticed a very heavy plasma cell infiltration of lymph nodes in mice with benign paraproteinaemia $>$ Several factors have been suggested as pre을. disposing to paraproteinaemia. Evidence for aू genetic factor comes from family studies. Spengler Butler, Fischer, Ryssel, Schmid, and Sieber (1966) found that in some families asymptomatic paraprow teinaemia occurred about 14 times as commonly as overt myelomatosis or macroglobulinaemia in cono trast to the ratio in the general population (tables fD $^{\circ}$ and II). These studies and others (Seligmann? Danon, Mihaesco, and Fudenberg, 1971; Grant, Blumenschein, and Buckley, 1971; Waldenström? 1973) also indicated a higher incidence of para 
proteinaemia in the families of affected individuals than in the general population. Moreover, Radl and Hollander (1974) have found a strain of mice, C57BL, in which $50 \%$ have a paraprotein in the serum by the age of 24 months, without evidence of malignancy. This strain may prove to be a most useful experimental model for the study of benign paraproteinaemia. The association of the latter with age has already been stressed, although the correlation with age may be indirect.

It may be postulated that a paraprotein represents a specific response to a particular antigen (Metzger, 1969; Potter, 1971; Danon and Seligmann, 1972) which could be either bacterial or viral (Mitchell, Rees, and Salisbury, 1971). However, the number of cases in which the paraprotein has been shown to possess specific antibody activity is relatively small, and of these the majority appear to be autoimmune antibodies. Anti-bacterial activity has been found in a small number of cases but, in general, attempts to show antibody activity in paraproteins have been unsuccessful. This perhaps is not surprising in view of the enormous number of possible antigens and man's almost unlimited capacity for antibody production.

Michaux and Heremans (1969) postulated that a benign paraproteinaemia is the result of activity of an escaped clone of limited autonomy in the absence of underlying disease and of any positive causative factor apart possibly from a genetic one. On rare occasions an escaped clone may gain complete autonomy and explode into malignancy.

It has been suggested by Laurell (1968) that clones which produce a paraprotein havelost the mechanism which normally governs multiplication and differentiation of antibody-producing cells. Complete loss of feedback inhibition could be the cause of unrestricted growth and malignancy, whilst a different mutation could result in a moderate increase in cell mass with the establishment of a new balance between proliferation and the defence mechanism, so that a stable level of serum paraprotein is maintained. Such a mutation may also result in an alteration of the amino-acid sequence which in turn results in imperfect self-recognition and weaker inhibition. It is suggested that mutation is facilitated by certain types of unusual or protracted reticuloendothelial cell stimulation in geneticallypredisposed or preconditioned hosts (Osserman, 1971). This is compatible with the relatively high incidence in old age as the number of antigens encountered accumulates with age.

It is possible to regard all paraproteinaemias as potentially malignant states which may remain in an asymptomatic, prodromal stage for a very long time. The relatively high ratio of myeloma to benign paraproteinaemia in old age makes this hypothesis quite plausible. Some inhibitory factors, very likely of an immunological nature, may be responsible for the latent period, for, if it is accepted that the cell mass in myeloma doubles in about six months it is necessary to explain why the serum paraprotein concentration may remain unchanged for a number of years. Unless a 'braking mechanism' of some sort be postulated, whether by feedback or immunological inhibition, the theory of a slowly but inexorably progressive malignant process is difficult to accept.

An interesting observation was made by Lindström, Hardy, Eberle, and Williams (1973) who reported that the total number of $B$ cells among peripheral blood lymphocytes is reduced in myeloma but not in benign paraproteinaemia. This is in agreement with the immunosuppression so often observed in myeloma. A new concept regarding the pathogenesis of immunocytomas has recently been put forward by Salmon and Seligmann (1974). These authors postulate that a 'two-hit phenomenon' is responsible for the development of a malignant immunocytoma. The first 'hit' is antigenic stimulation which leads to monoclonal B-cell proliferation. A second hit then acts as the mutagenic or oncogenic stimulus which produces malignant transformation in a susceptible subclone.

When overt malignant disease does supervene in cases previously classified as benign, which is in fact rare, it may be due to several factors other than slow progression of a condition which was malignant from the start. The possibilities include factors mentioned above as well as the emergence of a competitive malignant clone (Spengler, Steinberg, and Skvaril, 1972).

\section{Possible Future Developments in this Field}

In the future, studies of bone marrow cultures in vitro may throw light on some of the problems. Plasma cells in marrow cultures of malignant immunocytomas appear to undergo characteristic transformation within a relatively short period of time, whereas those from benign paraproteinaemias do not (Barandun, 1974, personal communication). Culture may also enable inhibitory factors to be demonstrated in benign conditions and there may possibly be some correlation between inhibitory levels and the rate of immunoglobulin production, as suggested by Dr Askonas (unpublished observations).

\section{Conclusions}

True benign paraproteinaemia is difficult to distinguish from the early stages of malignant para- 
proteinaemia and each case must be considered on its merits. Monitoring the serum concentration of the paraprotein (and particularly its increase) and of other immunoglobulins, together with examination of the urine for Bence-Jones protein, are the most valuable laboratory procedures. The protein abnormality should be confirmed and identified by appropriate immunochemical analysis. Serum hyperviscosity and the presence of cryoglobulins and cold agglutinins should also be taken into consideration.

In patients attending hospital with signs and symptoms of disease, paraproteinaemia should be regarded as potentially malignant until proved otherwise, especially if the serum paraprotein level exceeds $20 \mathrm{~g} / \mathrm{l}$ for IgG or $10 \mathrm{~g} / \mathrm{l}$ for IgA. A radiological survey of the skeleton as well as a marrow biopsy may be indicated. Such patients should be followed up for at least five years before concluding that the cause is benign. Even then the diagnosis cannot be regarded as certain.

Conversely, the incidental finding of paraproteinaemia in a population survey, or in patients without other signs or symptoms suggestive of malignancy, does not indicate the need for extensive investigations. The patient's doctor should be informed but not the patient, who may become unduly alarmed. Treatment should be withheld until evidence of malignancy is available.

In view of the possibility of a viral aetiology of myeloma, blood from donors with paraproteinaemia should not be used for transfusion (Kohn, 1971), particularly of patients in the younger age groups. There may even be a case for screening blood donors (Fine, Lambin, and Leroux, 1972).

\section{References}

Axelsson, U. and Hällén, J. (1968). Review of fifty-four subjects with monoclonal gammopathy. Brit. J. Haemat., 15, 417.

Axelsson, U., Bachman, R., and Hällén, J. (1966). Frequency of pathological proteins (M-compounds) in 6,995 sera from an adult population. Acta. med. scand., 179, 235.

Blundell, G., and Fitzpatrick, J. E. (1971). Paraproteinaemias-a laboratory survey. Irish J. med. Sci., 140, 176.

Cooke, B. (1969). Essential paraproteinaemia. Proc. roy. Soc. Med., 62, 777.

Danon, F., and Seligmann, M. (1972). Transient human monoclonal immunoglobulins. Scand. J. Immunol., 1, 323.

Dammacco, F., and Waldenström, J. (1968). Bence-Jones proteinuria in benign monoclonal gammapathies. Acta. med. scand., 184, 403-409.

Englisova, M., Englis, M., Kyral, V., Kourilek, K., and Dvorak, K. (1968). Changes of immunoglobulin synthesis in old people. Exp. Geront., 3, 125.

Fine, J. M., Derycke, C., and Boffa, G. A. (1966). Les formes atypiques et essentielles de dysglobulinémies. Rev. méd. Tours., $2,193$.

Fine, J. M., Lambin, P., and Leroux, P. (1972). Frequency of monoclonal gammapathy (M-components) in 13,400 sera from blood donors. Vox Sang. (Basel), 23, 336.

Grant, J. A., Blumenschein, G. R., and Buckley, C. E., III (1971). Familial paraproteinaemia. Arch. intern. Med., 128, 427.

Hällén, J. (1963). Frequency of 'abnormal' serum globulins (Mcomponents) in the aged. Acta med. scand., 173.

Hällén, J. (1966). Discrete gammaglobulin (m)-components in serum.
Acta med. scand., Suppl. 462.

Hobbs, J. R. (1967). Paraproteins, benign or malignant? Brit. med. J., 3, 699.

Hobbs, J. R. (1971a). Immunocytoma o' mice an' men. Brit. med.으

J., 2, 67.
Hobbs, J. R. (1971b). Immunoglobulins in clinical chemistry. Advanc clin. Chem., 14, 219.

Jensen, K., Hom, B. L., Jensen, K. B., and Olesen, H. (1969).ర Characterization of M-components in a large municipal $\frac{\mathrm{O}}{5}$ hospital. Dan. med. Bull., 16, 165.

Kohn, J. (1971). Is there risk in transfusing blood from donors with paraproteinaemia? (Letter), Lancet, 2, 1206.

Kohn, J. (1973). Laboratory investigation of paraproteinaemia. In Recent Advances in Clinical Pathology, Series 6, edited by S. C. Dyke, p. 363. Churchill Livingstone, Edinburgh and? London.

Kohn, J., and Srivastava, P. C. (1972). Paraproteins in blood donors and the aged, benign and malignant. Protides biol. Fluids., 20 257.

Kyle, R. A., and Bayrd, E. D. (1966). Benign monoclonal gammopathn -a potentially malignant condition? Amer. J. Med., 40, 426용

Kyle, R. A., Maldonado, J. E., and Bayrd, E. D. (1973). Idiopathie Bence-Jones proteinuria-a distinct entity? Amer. J. Med., 55, 222.

Laurell, C. B. (1968). The diagnostic significance of immunoglobuline M-components in clinical work. Scand. J. clin. Invest., 22, 83.

Lindström, F. D., Hardy, W. R., Eberle, B. J., and Williams, R. C., Jr N (1973). Multiple myeloma and benign monoclonal gammapathy 0 differentiation by immunofluorescence of lymphocytes. Ann intern. Med., 78, 837.

Metzger, H. (1969). Myeloma proteins and antibodies. Amer. J. Med.c $47,837$.

Michaux, J. L., and Heremans, J. F. (1969). Thirty cases of monoclona? immunoglobulin disorders other than myeloma or macro globulinemia. A classification of diseases associated with the production of monoclonal-type immunoglobulins. Amer. $J \overrightarrow{\vec{C}}$ Med., 46, 562.

Mitchell, D. N., Rees, R. J. W., and Salsbury, A. J. (1971). Possßler transmissibility of human myelomatosis in immunologicelly deficient mice. Lancet, 2, 1009.

Norgaard, O. (1964). Recherches sur l'évolution précliniqueç myélome multiple. Acta med. Scand., 176, 137.

Osserman, E. F. (1971). Multiple myeloma and related plasma cello

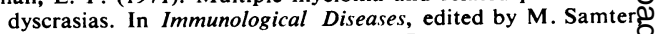
2nd ed., Vol. 1, p. 250. Little Brown, Boston

Osserman, E. F., and Fahey, J. L. (1968). Plasma cell dyscrasias@ current clinical and biochemical concepts. Amer. J. Med., 44 256.

Potter, M. (1971). Myeloma proteins (M-components) with antibody like activity. New Engl. J. Med., 284, 831.

Radl, J., and Hollander, C. F. (1974). Homogenous immunoglobulin in sera of mice during aging. J. Immunol., 112, 2271.

Salmon, S. E., and Seligmann, M. (1974). B-cell neoplasia in man Lancet, 2, 1230.

Seligman, M., Danon, F., Mihaesco, C., and Fudenberg, H. H. (1967) Immunoglobulin abnormalities in families of patients wit Waldenström's macroglobulinemia. Amer. J. Med., 43, 66.

Spengler, G. A., Butler, R., Fischer, C., Ryssel, H. J., Schmid, E尺 and Siebner, H. (1966). On the question of familiar occurrences of paraproteinaemia. Helv. med. Acta., 33, 208.

Spengler, G. A., Steinberg, A. G., and Skvaril, F. (1972). DevelopmenQ of a second monoclonal immunoglobulin $G$ in a patient with late manifestation of myeloma. Acta med. Scand., 192, 309. D

Stevens, A. R., Jr. (1965). Evolution of multiple myeloma. Arch intern. Med., 115, 90.

Waldenström, J. (1944). Incipient myelomatosis or 'essential' hypeß్ globulinaemia with fibrinogenopenia-a new syndrome? Acta. med. Scand., 117, 216.

Waldenström, J. (1973). Benign monoclonal gammapathies, multip传 myeloma and related disorders. In Multiple Myeloma ando Related Disorders, Vol. 1, edited by H. A. Azar and M. Potteg pp. 247-286. Harper and Row, Hagerstown, Md.

Walsh, N. P., McSweeney, J. R., and Russell, M. P. (1971). Par£ protein screening in a psychiatric hospital. J. Irish med. Ass 64, 12.

Young, V. H. (1969). Transient paraproteins. Proc. roy. Soc. Med 62, 778.

Zawadzki, Z. A., and Edwards, G. A. (1972). Nonmyelomatoug monoclonal immunoglobulinemia. Progr. clin. Immunol., 1, 1050 